\title{
Transgenic Canola Plants Expressing cry1la5 Gene Are Resistant to (Agrotis Ipsilon) Using Sonication Assisted Agrobacterium Mediated Transformation (SAAT) Technique
}

Research Article

Keywords:

Posted Date: February 25th, 2021

DOI: https://doi.org/10.21203/rs.3.rs-190901/v2

License: (1) This work is licensed under a Creative Commons Attribution 4.0 International License. Read Full License 


\section{Abstract}

The authors have requested that this preprint be withdrawn due to erroneous posting.

\section{Full Text}

The authors have withdrawn this preprint from Research Square. 